\title{
Efetividade antimicrobiana de protocolos de higienização de próteses totais de pacientes hospitalizados: ensaio clínico randomizado
}

\section{RESUMO}

Para minimizar os riscos de infecções respiratórias via prótese, reduzindo o tempo e os custos de hospitalização, é fundamental adotar um protocolo de higienização para remoção de biofilme protético quando da internação do paciente. Este estudo clínico randomizado avaliou, em pacientes hospitalizados, a efetividade de vários protocolos de higienização de próteses removíveis na redução do biofilme protético, a partir do uso de métodos mecânicos associados ou não a outros químicos e físicos de limpeza. Próteses totais superiores (PTS) de 160 pacientes internados no Hospital da Beneficência Portuguesa de Bauru foram limpas aleatoriamente, utilizando um dos protocolos a seguir, antes das mesmas serem imersas em água estéril por 3 min para enxágue $(n=20)$ : escovação com água destilada; imersão em solução química de limpeza (digluconato de clorexidina a $0,12 \%$ e $2 \%$ por $10 \mathrm{~min}$ ) ou irradiação por microondas (650 W/3 min) combinada ou não à escovação. Antes e após a aplicação dos protocolos, o biofilme protético foi corado para o cálculo da redução da área percentual de recobrimento visível (ImageJ), e culturas quantitativas microbiológicas da região interna da PTS foram obtidas em ágar sangue (UFC/mL). Esses dados foram submetidos aos testes de Wilcoxon e Kruskal-Wallis $(\alpha=0,05)$. Os fatores relevantes envolvidos com o biofilme protético e as hipóteses diagnósticas foram considerados na análise da amostra. Todos os protocolos testados resultaram em uma redução significativa na área percentual de biofilme protético e dos microrganismos viáveis nas culturas das PTS $(P<0,05)$. A comparação entre os protocolos mostrou a maior redução nas medianas de $\log _{10} \mathrm{UFC} / \mathrm{mL}$ e porcentagens de biofilme protético para as PTS que foram submetidas à escovação em associação à imersão em clorexidina a $2 \%$ ou irradiação por micro-ondas $(P<0,05)$. Embora tenha resultado em maiores porcentagens de biofilme visível $(P<0,05)$, a imersão em clorexidina a $2 \%$ isoladamente tão efetiva quanto os métodos combinados com escovação na redução dos valores de $\log _{10} \mathrm{UFC} / \mathrm{mL}(P>0,05)$. As hipóteses diagnósticas não influenciaram na presença do biofilme nem na efetividade os protocolos testados $(P>0,05)$. A escovação das próteses totais de pacientes hospitalizados em associação à irradiação por micro-ondas ou solução de clorexidina a $2 \%$ foram considerados os protocolos de higienização mais efetivos na redução do biofilme protético. Uma única imersão em clorexidina a $2 \%$ por 10 min também provou ser um método alternativo, mais rápido e aplicável ao ambiente hospitalar para redução de patógenos presentes nas próteses totais de pacientes hospitalizados.

Palavras-chave': Prótese Total. Higienizadores de Dentadura. Assistência Hospitalar.

1 Em acordo com os Descritores em Ciências da Saúde (DeCS) disponíveis no domínio: http://decs.bvs.br/ 